\title{
PENGARUH PUPUK ORGANIK LIMBAH PADAT INDUSTRI CRUMB RUBBER TERHADAP PERTUMBUHAN TANAMAN CABE (Capsicum frutescens)
}

\section{(THE INFLUENCE OF ORGANIC FERTILIZER OF CRUMB RUBBER SOLID WASTE INDUSTRY ON CHILI PLANTS (Capsicum frutescens) GROWTH)}

\author{
Supraptiningsih ${ }^{1)}$ \\ Email: ningsih1957@yahoo.com \\ Diterima: 8 September 2009 \\ Disetujui: 4 Agustus 2010
}

\begin{abstract}
The research about the influence of organic fertilizer of crumb rubber solid waste industry on chili plants (capsicum frutescens) growth had been done. The aim of the research was to evaluate the vegetative growth of chili plants treated with organic fertilizer that was made from crumb rubber solid waste industry and it was compared with chili plants treated was commercial organic fertilizer (SP-36). The organic fertilizer was made by mixing of soil, crumb rubber solid waste, cow fieces, talc, saw dust, and hull rices, using an aerob system. The variation of the amount of solid waste was $0 \% ; 10 \% ; 20 \% ; 30 \%$; and $40 \%$, respectively. Fertilizing of chili plants was done by dosage variation i.e 1; 1,5 ; and $2 \mathrm{~kg} / 10 \mathrm{~m}^{2}$ and control (without fertilizer) respectively. The observation was done on fourth month on vegetative growth including high plants, leaf length, and leaf width. The results showed that crumb rubber solid waste could be used as organic fertilizer for chili plants. The best growth of plants especcially high was treated with $20 \%$ crumb rubber solid waste at dosage of $2 \mathrm{~kg} / 1 \mathrm{~mm}^{2}$ is $38.2 \mathrm{~cm}$, while the best growth of leaf length and leaf width was chili plant treated with $40 \%$ crumb rubber solid waste at dosage of $2 \mathrm{~kg} / 10 \mathrm{~m}^{2}$ was $10.0 \mathrm{~cm}$ and $6.2 \mathrm{~cm}$.
\end{abstract}

Keywords: crumb rubber, solid waste, fertilizer, chili plants.

\begin{abstract}
ABSTRAK
Penelitian tentang pengaruh pupuk organik limbah padat industri crumb rubber terhadap pertumbuhan tanaman cabe (capsicum frutescens) bertujuan mengevaluasi pertumbuhan vegetatif tanaman cabe yang diberi limbah padat industri crumb rubber dibandingkan dengan tanaman cabe yang diberi pupuk organik dari pasaran (SP-36). Pupuk organik dibuat dengan mencampurkan tanah, limbah padat crumb rubber, kotoran sapi, kapur, serbuk gergaji, dan sekam, secara aerob dengan variasi jumlah limbah padat berturut-turut $0 \% ; 10 \% ; 20 \% ; 30 \%$; dan $40 \%$. Pemupukan tanaman cabe dilakukan dengan variasi dosis berturut-turut $1 ; 1,5$; dan $2 \mathrm{~kg} / 10 \mathrm{~m}^{2}$ serta dibuat kontrol tanpa pemupukan. Pengamatan dilakukan pada bulan ke 4, terhadap pertumbuhan tanaman cabe meliputi tinggi tanaman, panjang daun, dan lebar daun. Hasil penelitian menunjukkan bahwa limbah padat crumb rubber dapat dimanfaatkan sebagai pupuk organik untuk tanaman cabe. Perubahan tinggi tanaman paling besar pada pemberian pupuk $20 \%$ limbah padat crumb rubber dengan dosis $2 \mathrm{~kg} / 10 \mathrm{~m}^{2}$ sebesar $38,2 \mathrm{~cm}$, sedangkan perubahan panjang daun dan lebar daun paling besar pada pemberian pupuk $40 \%$ limbah crumb rubber dengan dosis $2 \mathrm{~kg} / 10 \mathrm{~m}^{2}$, yaitu panjang sebesar $10,0 \mathrm{~cm}$ dan lebar $6,2 \mathrm{~cm}$.
\end{abstract}

Kata kunci: crumb rubber, limbah padat, pupuk, tanaman cabe

\section{PENDAHULUAN}

Produksi crumb rubber membutuhkan bahan baku berupa bahan olah karet (bokar). Bokar digiling, dicuci berkali-kali sampai bersih baru kemudian dikeringkan dengan alat pengering (drier) dan selanjutnya dikempa menjadi bandela sebagai bahan baku pembuatan ban. Air bekas pencucian banyak mengandung debu, pasir, potongan-potongan kayu, asam cuka, dan tawas.
Air bekas pencucian tersebut disaring untuk memisahkan limbah padat dan cairan. Penanganan limbah cair, beberapa perusahaan crumb rubber telah melengkapi diri dengan IPAL (Instalasi Pengolah Air Limbah) (Salvato, 1972). Sementara limbah padat hanya ditumpuk/ditimbun di halaman pabrik dan menunggu warga setempat mengambil untuk digunakan sebagai penutup lahan (landfill). Rina dkk, (1992) mengatakan

\footnotetext{
${ }^{1)}$ Balai Besar Kulit, Karet dan Plastik, Yogyakarta
} 
bahwa limbah padat industri dapat digunakan untuk kompos. Limbah padat yang ditimbun dapat menimbulkan permasalahan baru apabila tidak segera diambil, karena bau menyengat dan air limbah dari air luruhan (leached water). Limbah padat tersebut mencemari lingkungan sekitar penampungan (Howard, 1982).

Mengingat proses awal pembuatan crumb rubber, maka limbah padat ini berasal dari kotoran-kotoran yang ada pada latex dan kadang sengaja dicampurkan oleh petani berupa pasir, kayu, dan zat-zat organik. Limbah padat industri crumb rubber tidak selalu harus dibuang, karena jumlah kandungan zat organiknya memungkinkan untuk dijadikan pupuk organik atau penyubur tanah melalui proses pembuatan kompos (Munir dkk, 2003). Kompos merupakan pupuk organik sebagai pemasok unsur hara yang diperlukan tanaman, dapat menambah kemampuan tanah dalam menyimpan air, menyerap pupuk tambahan lain, menciptakan lingkungan yang baik untuk kehidupan jasad renik, sehingga tanah jadi subur dan membantu pertumbuhan tanaman (Budi_Santosa, H., 1998). Menurut Glaug dan Galueke dalam Yulinda_Rosa (2000), pengomposan adalah proses dekomposisi secara biologis dan stabilitas bahan organik dibawah kondisi suhu tertentu yang dihasilkan dari panas akibat adanya aktivitas mikroorganisme yang berkembang biak di dalamnya dengan hasil yang cukup stabil untuk disimpan dan digunakan di dalam tanah tanpa merugikan lingkungan. Pemanfaatan pupuk organik dapat mengurangi penggunaan pupuk anorganik/pupuk kimia yang harganya relatif mahal, dan merusak tanah. Menurut hasil penelitian Outterbridge dan B. Thomas (1991) di Cina, penggunaan pupuk organik yang berasal dari limbah pertanian dapat menghemat pemakaian pupuk kimia sebesar 25$40 \%$.

Pemberian pupuk organik dapat meningkatkan kandungan unsur hara makro dan mikro di dalam tanah yang sangat diperlukan oleh tanaman. Fungsi pupuk organik dapat memperbaiki daerah perakaran sehingga memberikan media tumbuh yang lebih baik bagi tanaman (Suharto, 1997). Selain hal tersebut, pupuk organik juga dapat meningkatkan aktivitas mikroorganisme yang sangat bermanfaat dalam penyediaan hara tanaman (Murbandono, 2003). Penggunaan pupuk organik makin digalakkan karena mempunyai tiga keuntungan yaitu, penyelamatan lingkungan, menyuburkan tanah, dan memacu pertumbuhan tanaman.

Penelitian ini bertujuan untuk memantau pertumbuhan tanaman cabe yang diberi pupuk organik dari limbah crumb rubber. Hasil penelitian diharapkan dapat meningkatkan pemanfaatan nilai tambah limbah sebagai substitusi pupuk organik, dan dapat membantu menyelesaikan masalah penanganan limbah padat tersebut, serta dapat mengurangi pencemaran lingkungan.

\section{BAHAN DAN METODE PENELITIAN Bahan Penelitian}

Bahan-bahan penelitian terdiri atas: bibit tanaman cabe rawit (Capsicum frutescens) diperoleh dari pasar Kotagede Yogyakarta, limbah padat industri crumb rubber yang diperoleh dari PT Garuntang di Bandar Lampung, tanah, kotoran sapi dari peternak, kapur dari pasaran, pupuk komersial buatan SP-36, serbuk gergaji dari tempat penggergajian, dan abu sekam.

\section{Alat Penelitian}

Alat penelitian terdiri atas : Grinder (Toshiba), timbangan (Denver Instrument, seri 0067624), alat-alat pertanian (sekop, cangkul).

\section{Cara Penelitian}

Penelitian tentang evaluasi pertumbuhan tanaman cabe (Capsicum frutescens) hasil pemupukan dengan limbah padat industri crumb rubber dilakukan pada tanah jenis andosol. Pemilihan jenis tanaman cabe dengan pertimbangan bahwa tanaman cabe merupakan tanaman berumur pendek (semusim).Tanaman cabe yang digunakan adalah jenis cabe rawit.

\section{Pembuatan pupuk organik}

Pupuk organik dibuat dengan mencampurkan limbah padat industri crumb rubber dengan bahan-bahan dibuat dalam 5 formulasi seperti pada Tabel 1.

Tabel 1. Komposisi pupuk organik limbah padat industri crumb rubber

\begin{tabular}{|l|c|c|c|c|c|}
\hline \multirow{2}{*}{ Bahan } & \multicolumn{5}{|c|}{ Komposisi pupuk (\%) } \\
\cline { 2 - 7 } & P1 & P2 & P3 & P4 & P5 \\
\hline Tanah & 40 & 50 & 40 & 30 & 20 \\
Limbah padat & & & & & \\
crumb rubber & 0 & 10 & 20 & 30 & 40 \\
Pupuk komersial & & & & & \\
SP-36 & 20 & - & - & - & - \\
Kotoran sapi & 10 & 10 & 10 & 10 & 10 \\
Kapur & 10 & 10 & 10 & 10 & 10 \\
Serbuk gergaji & 10 & 10 & 10 & 10 & 10 \\
Sekam & 10 & 10 & 10 & 10 & 10 \\
\hline
\end{tabular}


Semua bahan dicampur hingga homogen, kemudian dibiarkan selama 40 hari. Pembuatan kompos organik dilakukan secara aerob atau secara terbuka dengan mengikuti pedoman "Membuat Kompos" (Murbandono, 2003). Suhu tumpukan bahan yang sedang dikomposkan harus mencapai $55^{\circ} \mathrm{C}$ dalam periode minimal 15 hari berturut-turut. Pencapaian suhu dalam selang waktu tersebut dimaksudkan untuk menjamin kompos yang dihasilkan bebas dari gulma dan patogen. Kelembaban bahan diusahakan sekitar $60 \%$ dengan cara menyiram air setiap hari, dan agar proses pengomposan berjalan lancar dan merata, tumpukan bahan dilakukan pembalikan (agitasi) seminggu sekali (Suharto, 1997). Proses pengomposan diakhiri setelah warna campuran tersebut berubah menjadi coklat kehitaman, dan jika digenggam kompak (Engelstad, 1997).

Pupuk PI adalah pupuk organik tanpa menggunakan limbah padat crumb rubber, tapi mengandung pupuk komersial SP-36.

\section{Rancangan Percobaan}

Perlakuan yang diperbandingkan pada penelitian ini terdiri atas 2 faktor:

Faktor pertama jenis pupuk organik yaitu tanpa penambahan limbah $(0 \%)$, penambahan limbah $10 \%, 20 \%, 30 \%$, dan $40 \%$.

Faktor kedua dosis pemupukan berturut-turut 1; 1,$5 ; 2 \mathrm{~kg} / 10 \mathrm{~m}^{2}$, dan dibuat kontrol (tanpa pemupukan).

Data pengamatan berupa pertumbuhan vegetatif tanaman dengan mengukur tinggi tanaman, panjang daun, dan lebar daun.

Data tersebut dianalisis menggunakan Rancangan Acak Kelompok Lengkap (Randomized Complited Block Design).

\section{Cara Pemupukan}

Pupuk organik hasil penelitian disebarkan secara merata pada tanah yang sudah siap ditanami, dengan berbagai variasi dosis (Novisan, 2002). Penanaman cabe pada penelitian ini menggunakan pupuk organik hasil komposting limbah padat industri crumb rubber. Obyek yang diamati adalah pertumbuhan vegetatif tanaman cabe meliputi pengukuran tinggi tanaman, panjang daun, dan lebar daun. Pengamatan pertumbuhan vegetatif dilakukan pada bulan ke 4 .

\section{HASIL DAN PEMBAHASAN}

Sebelum limbah padat crumb rubber dibuat kompos, limbah padat tersebut dianalisis terlebih dahulu komposisinya. Analisis komposisi limbah padat dilakukan di Institut Pertanian STIPER Yogyakarta, dan hasil analisis disajikan pada Tabel 2.

Tabel 2. Hasil analisis komposisi limbah padat industri crumb rubber

\begin{tabular}{|l|l|}
\hline \multicolumn{1}{|c|}{ Komponen } & \multicolumn{1}{c|}{ Hasil Analisis } \\
\hline $\mathrm{pH}$ & $4-5$ \\
$\mathrm{~N}$ Total(\%) & 12,38 \\
Carbon(\%) & 41,32 \\
P Total (ppm) & 4721,23 \\
Kalium (ppm) & 1835,27 \\
Zn (\%) & 0,02 \\
Ni (\%) & 0,01 \\
\hline
\end{tabular}

Limbah padat industri crumb rubber kemudian dibuat kompos dengan metode seperti dijelaskan di atas, dengan berbagai variasi menghasilkan pupuk organik P1, P2, P3, P4, dan P5. Pupuk organik tersebut dianalisis komposisinya dan hasil analisis disajikan pada Tabel 3.

Tabel 3. Hasil analisis komposisi kompos pupuk organik limbah padat industri crumb rubber.

\begin{tabular}{|c|c|c|c|c|c|c|c|}
\hline Jenis Pupuk & $\mathrm{pH}$ & $\begin{array}{l}\text { N total } \\
(\%)\end{array}$ & $\begin{array}{l}\text { P total } \\
(\mathrm{ppm})\end{array}$ & $\begin{array}{l}\text { Kalium } \\
(\mathrm{ppm})\end{array}$ & $\mathrm{Zn}(\%)$ & $\mathrm{Ni}(\%)$ & $\mathrm{C}(\%)$ \\
\hline $\begin{array}{l}\text { Pupuk organik } 1 \\
\text { (tampa limbah) }\end{array}$ & 6,34 & 7,91 & 3468,81 & 734,43 & 0,032 & 0,042 & 8,86 \\
\hline $\begin{array}{l}\text { Pupuk organik } 2 \\
\text { (ditambah limbah } 10 \% \text { ) }\end{array}$ & 6,05 & 8,22 & 3567,04 & 744,21 & 0,038 & 0,045 & 10,34 \\
\hline $\begin{array}{l}\text { Pupuk organik } 3 \\
\text { (ditambah limbah 20\%) }\end{array}$ & 5,61 & 8,79 & 3524,77 & 806,65 & 0,051 & 0,050 & 12,78 \\
\hline $\begin{array}{l}\text { Pupuk organik } 4 \\
\text { (ditambah limbah 30\%) }\end{array}$ & 5,51 & 8,80 & 3558,34 & 856,98 & 0,049 & 0,048 & 13,65 \\
\hline $\begin{array}{l}\text { Pupuk organik } 5 \\
\text { (ditambah limbah 40\%) }\end{array}$ & 5,52 & 9,17 & 3625,01 & 978,39 & 0,048 & 0,038 & 14,31 \\
\hline
\end{tabular}


Pada Tabel 3 terlihat bahwa analisis kompos dengan menggunakan limbah padat crumb rubber menunjukkan adanya kenaikan kandungan $\mathrm{N}, \mathrm{P}, \mathrm{K}$ seiring pertambahan limbah. Makin banyak limbah padat yang ditambahkan, makin besar kandungan $\mathrm{N}, \mathrm{P}, \mathrm{K}$. Variasi limbah $40 \%$ menunjukkan nilai $\mathrm{N}, \mathrm{P}, \mathrm{K}$ tertinggi, dengan estimasi tanaman menjadi lebih subur.

Pupuk organik yang sudah dibuat, diuji coba pada tanaman jangka pendek yaitu tanaman cabe. Pengamatan dilakukan pada bulan ke 4 terhadap pertumbuhan vegetatif tanaman yaitu tinggi tanaman, panjang daun, dan lebar daun.

Pengar'uh pupuk organik limbah padat industri crumb rubber terhadap tinggi tanaman.

Hasil uji coba pupuk organik limbah padat industri crumb rubber terhadap pertumbuhan vegetatif tanaman cabe dengan obyek pengamatan tinggi tanaman dapat dilihat pada gambar 1 sebagai berikut:

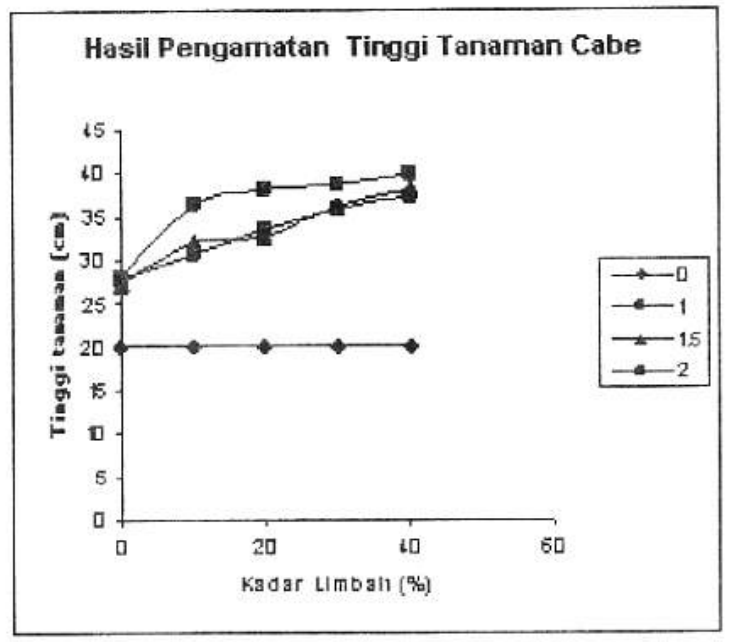

Gambar 1. Hasil pengukuran tinggi tanaman dengan pupuk organik limbah padat crumb rubber.

Dari gambar 1 tampak bahwa tanaman yang diberi pupuk organik limbah crumb rubber sampai dengan $40 \%$ dengan dosis $1 ; 1,5$; dan 2 $\mathrm{kg} / 10 \mathrm{~m}^{2}$ cenderung mengalami kenaikan tinggi tanaman. Pertumbuhan tanaman maksimum dicapai pada pemupukan $40 \%$ dengan dosis 2 $\mathrm{kg} / 10 \mathrm{~m}^{2}$ dengan tinggi tanaman $38,2 \mathrm{~cm}$. Dari analisa pupuk organik dengan kandungan limbah crumb rubber $40 \%$ adalah: $\mathrm{pH} 5,52 ; \mathrm{N}$ total 9,17 $\%$; P total 3625,01 ppm; Kalium 978,39 ppm; Zn 0,048 \%; Ni 0,038\%; dan C 14,31\%. Kualitas pupvk tersebut sangat mendukung pertumbuhan tanaman. Hal tersebut terbukti dengan pertumbuhan tanaman yang cukup tinggi ( 38,2 $\mathrm{cm}$ ).

Dari gambar 1 tersebut dapat dilihat bahwa pertumbuhan tanaman tertinggi dicapai pada pemberian pupuk organik dengan limbah padat $40 \%$ pada pemberian dosis $2 \mathrm{~kg} / 10 \mathrm{~m}^{2}$ yaitu $39,8 \mathrm{~cm}$ yang tidak berbeda nyata $(\mathrm{p}<0,05)$ dengan pemberian dosis 1 dan $1,5 \mathrm{~kg} / 10 \mathrm{~m}^{2}$ yaitu tinggi $37,2 \mathrm{~cm}$ dan $38,2 \mathrm{~cm}$, akan tetapi sangat berbeda nyata bila dibandingkan dengan tanaman yang tidak diberi pupuk (dosis 0), tinggi $20 \mathrm{~cm}$. Tanaman cabe mengalami pertumbuhan tertinggi sampai umur 4 bulan, dan setelah 5 bulan tidak mengalami pertambahan tinggi tanaman.

Pada pemberian pupuk organik dengan penambahan limbah padat $20 \%$, terlihat bahwa tanaman tertinggi dicapai pada pemberian dosis 2 $\mathrm{kg} / 10 \mathrm{~m}^{2}$ dengan tinggi $38,2 \mathrm{~cm}$ yang berbeda nyata dengan pemberian dosis 1 dan $1,5 \mathrm{~kg} / 10 \mathrm{~m}^{2}$ $(\mathrm{P}<0,05)$ tinggi $33,4 \mathrm{~cm}$ dan $32,8 \mathrm{~cm}$. Terdapat perbedaan sangat nyata dengan tanaman yang tidak diberi pupuk $(20 \mathrm{~cm})$ dan tanaman yang diberi pupuk tanpa limbah dosis $2 \mathrm{~kg} / 10 \mathrm{~m}^{2}$, yaitu $28,2 \mathrm{~cm}$.

Hasil pengamatan pemberian pupuk terhadap tinggi tanaman, tampak bahwa pupuk dengan penambahan limbah padat $10-40 \%$ berpengaruh sangat nyata terhadap tinggi tanaman. Pemberian pupuk sampai dosis $2 \mathrm{~kg} / 10 \mathrm{~m}^{2}$ dapat menaikkan tinggi tanaman dengan kecepatan pertumbuhan paling besar.

Pertumbuhan tanaman bila ditinjau dari pemberian dosis 1 ; 1,5 ; dan $2 \mathrm{~kg} / 10 \mathrm{~m}^{2}$, menunjukkan bahwa makin tinggi dosis yang diberikan, pertumbuhan tanaman makin tinggi. Tanaman tertinggi dicapai pada pemberian dosis 2 $\mathrm{kg} / 10 \mathrm{~m}^{2}$ pada setiap variasi jumlah limbah. Menurut penelitian Rina dkk, (1994) tentang pengaruh kompos limbah padat industri pulp dan kertas terhadap produktivitas tanaman holtikultur, menyatakan bahwa tinggi tanaman merupakan pertumbuhan vegetatif suatu tanaman, dimana pertumbuhannya sangat dipengaruhi oleh ketersediaan unsur nitrogen dalam tanah. Diduga unsur $\mathrm{N}$ total yang terkandung dalam kompos dapat diserap oleh akar tanaman. Kemungkinan N total yang terkandung dalam kompos selain terdiri dari $\mathrm{N}$ organik terdapat pula dalam bentuk amonia dan nitrat. $\mathrm{N}$ nitrat merupakan bentuk yang paling mudah terserap oleh akar tanaman.

Tanaman akan tumbuh subur bila semua 
elemen yang dibutuhkan ada, tersedia cukup dan dalam bentuk yang sesuai untuk diserap oleh tanaman. Setiap tanaman memerlukan paling sedikit 16 elemen untuk pertumbuhan normal, 3 elemen diperoleh dari udara dan 13 elemen dari dalam tanah (Thomson dan Kelly, 1978). Dari 13 elemen tersebut hanya 3 unsur makro yang mutlak harus ada bagi tanaman, yaitu N,P, dan K (Dwijoseputro, 1978). Limbah padat crumb rubber mengandung 3 unsur makro tersebut, sehingga dapat menjadikan tinggi tanaman bertambah, walaupun peningkatan dosis pupuk tidak selamanya berbanding lurus dengan pertumbuhan tinggi tanaman. Bila dibandingkan dengan tanaman yang tidak diberi pupuk (dosis 0 ), ternyata tinggi tanaman dengan pemberian pupuk dengan limbah $20 \%$ dan $40 \%$ sangat berbeda nyata lebih tinggi.

Pengaruh pupuk organik limbah padat industri crumb rubber terhadap panjang daun tanaman cabe.

Hasil uji coba pupuk organik limbah padat industri crumb rubber terhadap pertumbuhan vegetatif tanaman cabe dengan obyek pengamatan panjang daun tanaman dapat dilihat pada gambar 2 .

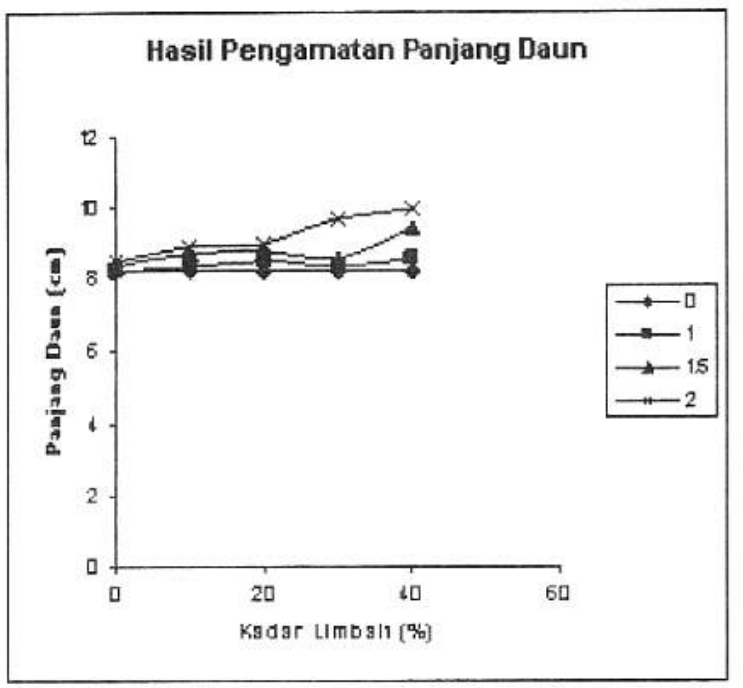

Gambar 2. Hasil pengukuran panjang daun dengan pupuk organik limbah padat crumb rubber.

Dari gambar 2 tersebut dapat dilihat bahwa nilai panjang daun tertinggi dicapai pada pemberian pupuk organik dengan penambahan limbah padat crumb rubber $40 \%$ pada pemberian dosis $2 \mathrm{~kg} / 10 \mathrm{~m}^{2}$ yaitu $10,0 \mathrm{~cm}$, yang tidak berbeda nyata dengan pemberian dosis $1,5 \mathrm{~kg} / 10 \mathrm{~m}^{2}$ yaitu $9,4 \mathrm{~cm}$, tetapi berbeda nyata dengan pemberian dosis $1 \mathrm{~kg} / 10 \mathrm{~m}^{2}$ dan tanaman tanpa pupuk (dosis 0 ) yang mempunyai panjang daun $8,6 \mathrm{~cm}$ dan 8,2 $\mathrm{cm}$. Tanaman cabe mengalami pertumbuhan panjang daun mulai umur 2 bulan, dan pengamatan sampai umur tanaman 4 bulan tidak mengalami pertambahan panjang daun yang signifikan.

Pada pemberian pupuk dengan penambahan limbah padat $20 \%$, terlihat bahwa pertumbuhan panjang daun cenderung naik. Pemberian pupuk dengan limbah padat $20 \%$ dosis 1; 1,5 ; dan $2 \mathrm{~kg} / 10 \mathrm{~m}^{2}$ tidak menunjukkan perbedaan yang nyata $(p<0,05)$ pada pertumbuhan panjang daun. Dari hasil pengamatan pemberian pupuk hasil penelitian terhadap panjang daun, tampak bahwa hanya pupuk dengan limbah padat $40 \%$ yang berpengaruh sangat nyata terhadap panjang daun.

Hasil pengamatan yang tertera pada gambar 2 menunjukkan bahwa pemberian pupuk dengan limbah padat $40 \%$ dapat memperoleh panjang daun yang lebih dari pada pemberian pupuk tanpa limbah padat crumb rubber dan pupuk dengan panambahan limbah padat yang lebih kecil $(10 \%, 20 \%$, dan 30\%). Hal ini berarti makin banyak jumlah limbah padat crumb rubber yang digunakan, akan menyebabkan daun lebih panjang atau tanaman lebih subur. Dari hasil analisis komposisi limbah dan komposisi pupuk hasil penelitian, ternyata makin banyak jumlah limbah crumb rubber yang digunakan dalam pembuatan pupuk, kandungan unsur $\mathrm{N}, \mathrm{P}$, dan $\mathrm{K}$ meningkat, sehingga nutrisi yang diberikan pada tanaman bertambah dan tanaman menjadi lebih subur. Bila dibandingkan dengan tanaman yang tidak diberi pupuk (dosis 0), ternyata panjang daun tanaman dengan pemberian pupuk yang diberi limbah $40 \%$ sangat berbeda nyata dengan yang lain.

Dari gambar 2 tampak bahwa tanaman yang diberi pupuk organik limbah crumb rubber sampai dengan $40 \%$ dengan dosis $1 ; 1,5$; dan 2 $\mathrm{kg} / 10 \mathrm{~m}^{2}$ cenderung mengalami kenaikan panjang daun. Pertumbuhan tanaman maksimum dicapai pada pemupukan $40 \%$ dengan dosis $2 \mathrm{~kg} / 10 \mathrm{~m}^{2}$ dengan panjang daun $10,0 \mathrm{~cm}$. Menurut Rina dkk, (1994), pada umumnya tanaman menyerap $\mathrm{N}$ dalam bentuk nitrat. Nitrat sangat mudah larut dalam air dan bila tidak dipergunakan oleh tanaman akan hilang tercuci. Tersedianya fosfat untuk tanaman adalah sangat berhubungan dengan pH. Pada pH 5-7, fosfat berada dalam bentuk mono 
atau dikalsium fosfat dan mudah terserap tanaman. Kalium bersifat katalisator terutama dalam metabolisme karbohidrat. Pencucian kalium berbeda-beda tergantung pada tipe tanah dan jumlah bahan organik dalam tanah. Dari analisa pupuk organik dengan kandungan limbah crumb rubber $40 \%$ adalah: $\mathrm{pH} 5,52 ; \mathrm{N}$ total $9,17 \%$; $\mathrm{P}$ total 3625,01 ppm; Kalium 978,39 ppm; Zn 0,048 \%; Ni $0,038 \%$; dan C 14,31 \%. Kualitas pupuk tersebut sangat mendukung pertumbuhan tanaman. Hal tersebut terbukti dengan makin banyak menggunakan limbah padat, pertumbuhan tanaman makin subur dan daun makin panjang

Pengaruh pupuk organik limbah padat industri crumb rubber terhadap lebar daun tanaman cabe.

Hasil uji coba pupuk organik limbah padat industri crumb rubber terhadap pertumbuhan vegetatif tanaman cabe dengan obyek pengamatan lebar daun tanaman dapat dilihat pada gambar 3 .

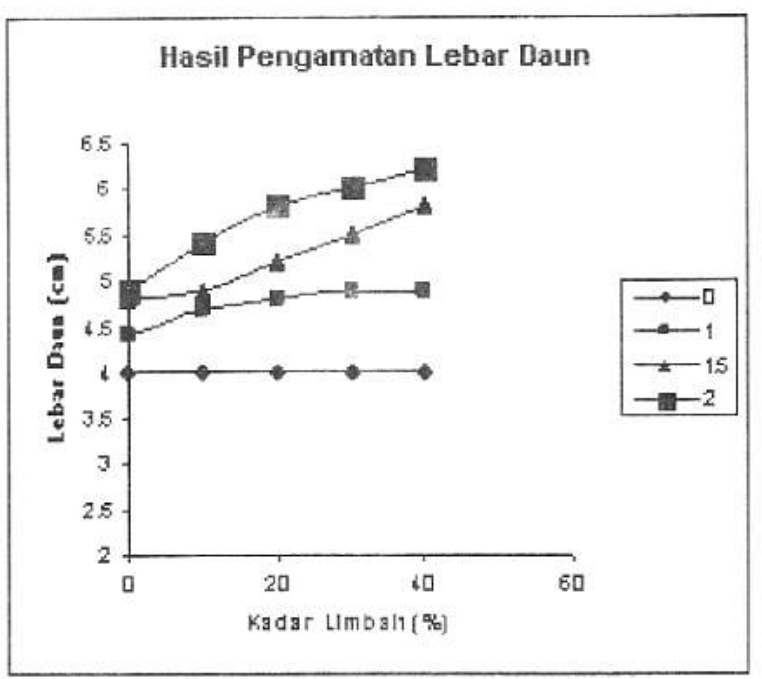

Gambar 3. Hasil pengukuran lebar daun dengan pupuk organik limbah padat crumb rubber.

Gambar 3 menunjukkan bahwa nilai lebar daun tertinggi yang dapat dicapai pada pemberian pupuk organik tanpa limbah adalah pada pemberian dosis $2 \mathrm{~kg} / 10 \mathrm{~m}^{2}$ sebesar $4,9 \mathrm{~cm}$, yang tidak berbeda nyata dengan pemberian dosis 1 , dan $1,5 \mathrm{~kg} / 10 \mathrm{~m}^{2}$ (4,4 cm dan 4,8 cm). Tanaman cabe mengalami pertumbuhan lebar daun mulai umur 2 bulan, dan pengamatan sampai umur tanaman 4 bulan tidak mengalami pertambahan lebar daun yang signifikan. Pada tanaman yang tidak diberi pupuk (dosis 0), hasil pengamatan menunjukkan nilai lebar daun tampak rendah dan berbeda nyata dengan pemberian pupuk dosis yang lainnya.

Pada pemberian pupuk dengan limbal $10 \%$, terlihat bahwa pertumbuhan lebar daus cenderung naik seiring dengan umur tanaman Pemberian pupuk dengan limbah padat $20 \%$ dosi 1; 1,5 ; dan $2 \mathrm{~kg} / 10 \mathrm{~m}^{2}$ tidak menunjukka1 perbedaan yang nyata pada pertumbuhan leba daun.

Pada pemberian pupuk dengan limbal $40 \%$, nilai lebar daun tertinggi dicapai ole] tanaman dengan pemberian pupuk dosis $2 \mathrm{~kg} / 10 \mathrm{~m}$ sebesar $6,2 \mathrm{~cm}$ yang tidak berbeda nyata dengar pemberian pupuk dosis $1,5 \mathrm{~kg} / 10 \mathrm{~m}^{2}$ sebesar 5 , $\mathrm{cm}$, tetapi berbeda nyata dengan pemberian pupul dosis $1 \mathrm{~kg} / 10 \mathrm{~m}^{2}$ dan dosis 0 (tanpa pupuk), yait sebesar $4,9 \mathrm{~cm}$ dan $4,0 \mathrm{~cm}$.

Dari hasil pengamatan pemberian pupu hasil penelitian terhadap lebar daun, tampa bahwa hanya pupuk dengan limbah padat $40 \%$ yang berpengaruh nyata terhadap lebar daun.

Hasil pengamatan menunjukkan bahwa pemberia pupuk dengan limbah padat $40 \%$ dapa memperoleh lebar daun yang lebih dari pad pemberian pupuk tanpa limbah, dan pupuk denga limbah $20 \%$. Hal ini berarti, makin banyak jumla limbah padat crumb rubber yang digunakan, aka menyebabkan daun lebih lebar atau tanaman lebi subur. Tanaman lebih tinggi, daun lebih panjan dan daun lebih lebar menunjukkan tanaman lebi subur (Anonim, 1987). Dari hasil analisi komposisi limbah dan komposisi pupuk has penelitian, ternyata makin banyak jumlah limba crumb rubber yang digunakan dalam pembuata pupuk, kandungan unsur $\mathrm{N}, \mathrm{P}$, dan $\mathrm{K}$ meningka sehingga nutrisi yang diberikan pada tanama bertambah dan tanaman menjadi lebih subu Lebar daun merupakan pertumbuhan vegetat tanaman yang pertumbuhannya sanga dipengaruhi oleh ketersediaan unsur-unsu tersebut. Bila dibandingkan dengan tanaman yan tidak diberi pupuk (dosis 0), ternyata lebar dau dengan pemberian pupuk yang diberi limbah $40^{\circ}$, berbeda nyata dengan pupuk yang lain pada usi tanaman $4-5$ bulan.

Analisa pupuk organik menunjukka bahwa bila kandungan limbah crumb rubber pad pupuk meningkat, maka meningkatkan kandunga $\mathrm{N}, \mathrm{P}$, dan $\mathrm{K}$. nya. Kualitas pupuk tersebut sange mendukung pertumbuhan tanaman. Hal tersebr terbukti dengan makin banyak menggunaka limbah padat, pertumbuhan tanaman makin subv dan daun makin lebar. 


\section{KESIMPULAN}

1. Pupuk organik limbah crumb rubber secara teknis dapat dimanfaatkan sebagai pupuk tanaman cabe dan dapat meningkatkan pertumbuhan vegetatif seperti tinggi tanaman, panjang daun, dan lebar daun. Pada penambahan limbah padat crumb rubber $40 \%$ dosis $2 \mathrm{~kg} / 10 \mathrm{~m}^{2}$ memberikan pertumbuhan tanaman cabe paling besar yaitu : tinggi tanaman 38,2 $\mathrm{cm}$, panjang daun $10 \mathrm{~cm}$, dan lebar daun $6,2 \mathrm{~cm}$.

2. Pupuk organik limbah crumb rubber memberikan perkembangan tanaman cabe lebih baik daripada tanaman tanpa pupuk dan tidak berbeda nyata dengan pupuk organik lainnya.

\section{DAFTAR PUSTAKA}

Anonim, 1987. Pemupukan Berimbang, Departemen Pertanian, Proyek Informasi Pertanian, Daerah Istimewa Yogyakarta, hal 1-4.

Budi_Santosa. H., 1998. Pupuk Kompos Technologi Tepat Guna, Percetakan Kanisius, Yogyakarta

Dwijoseputro, 1978. Pengantar Fisiologi Tumbuhan, PT Gramedia, Jakarta.

Engelstad, O.P., 1997. Teknologi dan Penggunaan Pupuk, diterjemahkan oleh Didiek Hadjar Goenadi, Gadjah Mada University Press, Yogyakarta.

Howard, G.F., 1982. Industrialization of US Agriculture an Interpretive Atlas, Westriew Press Inc, 5500 Central
Avenue Boulder, Colorado.

Munir, M., Moertinah, S, Sartamtama, 2003. Penelitian Pemanfaatan Limbah Padat Industri MSG untuk Pupuk Organik, Proceeding Workshop Hasil Litbang Bidang Pengendalian Pencemaran, Balai Besar kulit, Karet, dan Plastik, Yogyakarta.

Murbandono, H.L., 2003. Membuat Kompos, Edisi Revisi, Penebar Swadaya, Jakarta, hal 6-9.

Novisan, 2002. Petunjuk Pemupukan yang Efektif, Agro Media Pustaka, Jakarta.

Outterbridge, Thomas B., 1991. Limbah Padat di Indonesia, Masalah atau Sumber Daya, Yayasan Obor Indonesia.

Rina, S.S., R. Panggabean, S. Purwati, Tatang dan Suwandi, 1992. Pemanfaatan Limbah Padat Industri Pulp dan Kertas sebagai Kompos, Berita Selulosa, Vol 1 (32) 2:, Bandung.

Salvato, J.A., 1972. Environmental Engineering and Sanitation, Wiley-Intercicoce, New York.

Suharto, 1997. Metode Pembuatan Kompos, Lembah Hijau Multifarm, Surakarta.

Thomson,C.H., and Kelly, W.C., 1978. Vegetables Crops, $5^{\text {th }}$ edition, Mc Graw Hill Publishing Co., Ltd., New Delhi.

Yulinda_Rosa, 2000. Menentukan Masa Pengomposan Sampah Organik dengan Campuran EM4 dan Dedak Menggunakan Rancangan Percobaan Faktorial, Jurnal Penelitian Permukiman, Vol 16(2), Jakarta. 